This work is licensed under a Creative Commons Attribution 4.0 International License.

Ovaj rad dostupan je za upotrebu pod licencom Creative Commons Imenovanje 4.0 međunarodna.

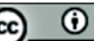

\section{Selma RALJEVIĆ}

Univerzitet „Džemal Bijedić“ u Mostaru

Sjeverni logor bb, Univerzitetski kampus

$\mathrm{BiH}-88104$ Mostar

selma.raljevic@unmo.ba
UDK 821.163.4(497.6).09 Mehmedinovića, S.-31 DOI: https://doi.org/10.29162/ANAFORA.v7i1.1

Izvorni znanstveni članak

Original Research Article

Primljeno 22. studenoga 2019.

Received: 22 November 2019

Prihvaćeno 28. siječnja 2020.

Accepted: 28 January 2020

\title{
POLIŽANROVSKA I TRANSDISKURZIVNA TEKSTUALNOST (TRANS)ROMANA ME'MED, CRVENA BANDANA I PAHULJICA SEMEZDINA MEHMEDINOVIĆA
}

\section{Sažetak}

Me’med, crvena bandana i pahuljica hibridni je roman Semezdina Mehmedinovića, objavljen 2017., koji svoju priču kazuje primjenom medija konceptualne umjetnosti. Između ostalih, on se bavi temama identiteta, sjećanja i njihova gubitka, traume, rata, migracija, pripadanja, nostalgije, zdravlja, obitelji, ljubavi i umjetnosti. Kako je sam trasnacionalni postjugoslavenski bosanskohercegovačko / južnoslavensko / istočnoeuropsko-američki književnik s imigrantskim iskustvom, Mehmedinović propituje normirane pojmove i shvaćanja identiteta time što istražuje konstrukcije i osobnog i društvenog identiteta, ali i identiteta narativa, čime se remete i poništavaju ideje „čistog“ identiteta. Njegov roman, u svom poližanrovskom, transdiskurzivnom i transumjetničkom narativu, iskazuje potrebu odbacivanja ideje čistog identiteta i, umjesto toga, prihvaćanja hibridnosti koja, između ostaloga, podrazumijeva koegzistenciju različitosti, dekonstrukciju binarnih konstrukcija (bilo između nacija, kultura, rasa, klasa ili rodova), te reflektira i (pre)oblikuje mnoge ključne pojave 
suvremenog ljudskog iskustva, pri čemu njegov tekst i kontekst funkcioniraju kao način i/ili zaziv prevladavanja „zamišljenih“ granica i artikulacija glasa neasimilacijskog identiteta drugotnosti.

Ključne riječi: Me’med, crvena bandana i pahuljica, Semezdin Mehmedinović, hibrid, poližanrovski, transdiskurzivni i transumjetnički narativ, identitet, sjećanja, zaborav

Semezdin Mehmedinović je trasnacionalni postjugoslavenski bosanskohercegovačko / južnoslavensko / istočnoeuropsko-američki književnik koji svoja djela već godinama prvobitno i ponajprije objavljuje u Hrvatskoj. Zbog toga se može reći da njegova književnost pripada i hrvatskoj književnosti, ali i općenito svim ex-jugoslavenskim i postjugoslavenskim književnostima srodnim na osnovu nekadašnjeg jednog jezika ${ }^{1}$ koji je bio i Mehmedinovićev, te na čijoj osnovi on i stvara svoj vlastiti hibridni književni jezik u sinergiji jezikā, ali i umjetničkih diskursa svoga života, odnosno svojih životā. Svoja književna djela ne piše na engleskom jeziku, ali u njima oslovljava i američku (po)javnost, pa je jedan od identiteta njegove književnosti, kao i njegove ličnosti, i (trans) američki. ${ }^{2}$ Rođen je 1960. u Kiseljaku, u bivšoj Jugoslaviji, a današnjoj Bosni i Hercegovini. Jedan dio života proveo je u Sarajevu, gdje je i završio studij Komparativne književnosti i bibliotekarstva. U Sarajevu je proveo i rat. Tek pred kraj opsade Sarajeva, krajem 1995., emigrirao je iz Bosne i Hercegovine i imigrirao u Sjedinjene Američke Države, gdje je većinu vremena živio u Arlingtonu, u Virginiji. U ljeto 2019. vratio se na svoju sarajevsku adresu i u svoj jezik. ${ }^{3}$ Svoju

\footnotetext{
${ }^{1}$ Mehmedinović u vezi s tim kaže: „Tako je maloljudan ovaj teritorij, tako je malo ljudi ovdje, da je potpuno apsurdno da postoje kontinuirani sukobi između grupa ili između naroda. Potpuno je apsurdno da jedno jedinstveno jezičko područje nema jedinstveno tržište knjiga. Potpuno je apsurdno da u ovim različitim našim nesretnim državicama ne prihvatamo pisce iz tog jezika kao vlastite pisce." (Nikolić)

${ }^{2}$ Caren Irr, naprimjer, kaže: „a work counts as part of 'U.S. fiction' not on the basis of the author's birthplace, citizenship, current residence, or workplace. Any of these biographical factors may be pertinent to any individual author's narrative, but no single data point (or combination) defines Americanness ... More important than biographical markers ... is an explicit effort to address a North American audience. The inclusion of major or minor American characters who are in some way educated by the international scene but are otherwise incidental to the story is one major indication that an author is addressing an American audience. Other signals of this concern include the preoccupation with correcting stereotypical American ideas about a particular region or the (often inverted or displaced) use of a common American narrative, such as the upwardly mobile immigrant story. In general, I view internal evidence such as voice, style, and narrative frame as more reliable indicator of a particular work's having an American reference point than authorial biography." (2014: 11)

${ }^{3}$ Povratkom u Bosnu i Hercegovinu i Sarajevo „ja sam se vratio, zapravo, u jezik“ (Otvaranje V. književnog festivala Poligon). Taj jezik je jezik države koja se „već davno raspala... [S]lovenski, u zajed-
} 
književnost koju je pisao u svom američkom dijelu života i koja mu se događala $\mathrm{u}$ engleskom jeziku simultano je prevodio ${ }^{4} \mathrm{u}$ samom procesu stvaranja, kako to sam zapisuje, „u jedan usamljeni, prilično dalek jezik (kojim govori relativno mali broj ljudi, tako da mi je zamisliv njegov nestanak u budućnosti)“ (2017: 141). Njegovu opstanku uvelike doprinosi i Mehmedinović svojim izborom pisanja i izvornog objavljivanja svoje književnosti na svom malom jeziku. On dodaje: „Neki detalji nisu prevodivi. Naša usamljenost najčistije se pokazuje u praznini koja nastaje između dva jezika. Ali ta praznina nije isto što i zaborav“ (2017: 141). Također, njegov vlastiti jezik, a time i jezik njegove književnosti, jest živi jezik njegova vlastitog dvojezičnog življenja života. Tako on neke riječi iz engleskog jezika, bez njihova prevođenja, životno i živo, odnosno kao živu materiju, unosi u jezik svoga književnog teksta na svom materinskom jeziku. Unutar njega, on tek povremeno i nakratko prebacuje jezični kôd u vidu jezičnog izmjenjivanja (prema engl. code-switching i/ili code-mixing i/ili language alternation) na engleski jezik. Osim toga, Mehmedinović u svoj književni tekst ugrađuje i jezik crteža. Preciznije, njegovi vlastiti crteži postaju dio njegova originalnog hibridnog književnog jezika i književnog teksta, kakav je slučaj njegova nagrađivanog romana Mémed, crvena bandana i pahuljica, objavljenog 2017. u izdanju hrvatske izdavačke kuće Fraktura. Dodatno, i između ostaloga, njegov književni jezik, a time i književni tekst, sadrže i prozne i/ili poetske slike (dakle, slike satkane u/od riječi) koje imaju kinematografske i/ili fotografske elemente. Njegov Me'med, crvena bandana i pahuljica je transnacionalni ${ }^{5}$ (trans)roman, ${ }^{6}$ čiji je književni tekst slobodan, otvoren i „živ“ i u vidu forme i u vidu sadržaja. Relativno u duhu izraza nekog, uvjetno rečeno, novog realizma, Mehmedinovićev je roman, također, život(vor)an u smislu pretvorbe piščeva vlastita života

ničkoj državi je također bio naš. Jednom, davno, postojao je svijet u kojem smo različite jezike zvali našim." (Mehmedinović 2017: 74)

${ }^{4}$ Preciznije, za roman Me’med, crvena bandana i pahuljica, Mehmedinović to objašnjava ovako: „Možda sam u krivu, ali ja mislim da je važan dramski okvir ove knjige to što opisujem događaje koji su mi se dogodili u engleskome, pa ih onda simultano, u tekstu, sebi prevodim." (Ljevak)

${ }^{5}$ Prema, recimo, široj definiciji Stevena Vertoveca, između ostalih, transnacionalizam podrazumijeva mnogostruke veze i interakcije koje povezuju ljude i institucije preko granica koje predstavlja nacija - država (usp. 2009: 1).

${ }^{6}$ „Roman koji u romaneskni izraz transponira izraz drugih žanrova u smislu nove otvorenosti djela i nove dijalektike između svih sadržaja savremenosti, i koji te sadržaje koristi kao 'alate' u književnom instrumentariju kako bi stvorio priču kao umjetničko djelo na isti način na koji stolar koristi čekić da bi na kraju napravio sto, kako bi to rekao William Faulkner, jedan od najvažnijih američkih romanopisaca modernizma, nazvala bih 'transromanom." (Raljević 2016: 21) 
u tekst, ${ }^{7}$ odnosno „fakcije“ u „fikciju“, ili, bolje reći, realnosti u prozu, i to lirsku prozu. Time pisac, metaforički rečeno, prevodi život u književni jezik. O tome bilježi:

Skoro sve važno što mi se dogodilo već sam opisao u svojim prozama i pjesmama i tako svoj život pretvorio u fikciju. To je sad zbir iluzija, dovoljno nepouzdanih, te se od njih teško može sastaviti faktografski popis mog života. (2017: 114)

Drugim riječima, Mehmedinović je tekst svoga romana „izjednačio sa svojim životom, a da nije pisao autobiografiju“ (Jergović). Međutim, isto tako kaže i da je svako naše sjećanje fikcija, te da „izvan te fikcije ne postojimo“ (Bašić 2018: 115). Tekstura romana Mémed, crvena bandana i pahuljica Semezdina Mehmedinovića je, između ostaloga, poližanrovska i transdiskurzivna, i na razini forme i na razini sadržaja. On se, baš poput i samog autora (ali i životne pojavnosti suvremenosti koju, u svim aspektima, pa tako, umnogome, i u književnosti, karakterizira kretanje, a onda i transdiskurzivnost), odupire „čistim formama" (Bašić 2018: 115). U skladu s tim, Mehmedinovićev je roman hibrid koji je, zapravo, kao takav, original. Njegova identitetska heterogenost propituje i prevladava postojeće granice bilo kojeg oblika ili forme jer „, hibridnost jedino i može postojati u svijetu s granicama“ (usp. Smith 2008: 6). Time on - i sam roman i autor, također, svojim bitkom i bivanjem - prevodi i književni jezik, odnosno književnost, u život. Roman kao žanr, na osnovu svoje neodređenosti i rastezljive, prilagodljive i upijajuće teksture u svojoj otvorenosti i odnosu prema različitim mogućnostima, predstavlja književni fenomen beskonačnog i fluidnog konstrukta koji je, kao takav, i mobilan - pokretan i promjenjiv, a onda i najpuniji i najautentičniji izraz većinom svake suvremenosti. $S$ obzirom na to da suvremenost današnjice posebno karakteriziraju upravo mobilnost, pokretnost i migracije različitog tipa ${ }^{8}$ kao i razvoj novih tehnika i tehnologija, te pri svemu tome dolazi i do dodira i spoja različitih sadržaja suvremenosti, i suvremeni roman odražava takve i druge životne pojave (a često se događa i da forma i/ili sadržaj književnosti prethodi nekoj formi i/ili sadržaju života). Tako su neke od

\footnotetext{
${ }^{7}$ Prema Mehmedinoviću, roman i jest ispričan život jednog čovjeka, što mu je, dakle, svakako i jedna od definicija (usp. Otvaranje V. književnog festivala Poligon).

${ }^{8}$ Vidi, naprimjer, sljedeće: „The twenty-first century will be the century of the migrant. At the turn of the century, there were more regional and international migrants than ever before in the recorded history ... It has become more necessary for people to migrate because of environmental, economic, and political instability ... In other ways, we are all becoming migrants. People today relocate to greater distances more frequently than ever before in human history." (Nail 2015: 1)
} 
mogućih karakteristika suvremenog romana politekstualnost, polidiskurzivnost i polidisciplinarnost izraza suvremenosti. Ovaj će se rad upravo i baviti poližanrovskom i transdiskurzivnom tekstualnosti romana Mémed, crvena bandana $i$ pahuljica Semezdina Mehmedinovića, kakav je, između ostaloga, i njegov život.

$\mathrm{U}$ (pri)vidu izdvojenog fragmenta na samom kraju romana koji predstavlja (auto)biografsku bilješku o autoru u trećem licu jednine s povremenim autoreferencijalnim upadicama glasa u prvom licu jednine, a što, zapravo, funkcionira kao crtica koja je dio teksta romana, stoji:

Semezdin Mehmedinović (1960.) piše hibridne tekstove, izbjegava čiste forme, jer zazire od političkog koncepta čistih identiteta. Prema rezultatima njegova DNK testa, on u svojim genima ima juga Europe, pojavljuju se Italija/Grčka u visokom postotku (20\%) (a to su valjda mediteranski geni kod svih rođenih na Balkanu), ima srednje i istočne Europe, ima 4\% finskih (skandinavskih), sjevernih gena („Eto, zbog čega toliko volim snijeg!“), u malom omjeru (2\%) zapadnoeuropskih („To su iza sebe ostavili križari na putu prema istoku“) i $2 \%$ kavkaskih gena. Dakle njegovo je porijeklo ekskluzivno europsko, s malo zapadne Azije. Svojom genetskom mapom on tako potvrđuje svu besmislenost balkanskog koncepta čistih identiteta. U šali se ponekad predstavlja kao Viking, a svojoj se životnoj suputnici zna obratiti i povjerljivom izjavom - „Ja sam tebi, dušo, stari Rimljanin.“ (Mehmedinović 2017: 174)

I kao svoj književni lik i/ili narator odvojen od autora i kao sam autor, te kao splet tih instanci, a onda i kao transmigrant u svom stvarnom životu, odnosno kao osoba koja razvija svoj identitet u istovremenoj poveznici s dvije ili više kultura, društava i nacija (usp. Schiller et al. 1992: 1-24), Mehmedinović je, kako sam za sebe kaže, „ontološki stranac“ (Ljevak). O sebi, također, veli da je iz Bosne i Hercegovine otišao i počeo živjeti u Americi u godinama u kojima je bio formirana ličnost, i dodaje:

Tada sam imao 35 godina. Mijenjati tu ličnost, u smislu potpunog mijenjanja identiteta nije bilo moguće. Proveo sam dvadeset i nešto godina $u$ SAD-u. Izvjesne identitetske osobine, koje prepoznajem kod sebe, a koje su nastale kao posljedica života u SAD-u, su evidentne. Dijeli[m] sada množinu identiteta. Spadam u onu vrstu ljudi koji odbija prihvatiti koncept jednog, čistog identiteta, kao da imaš taj identitet i drugi ne postoji. Pristalica sam ne onoga ili-ili, nego i-i (Nikolić), koncept[a] ... koji po- 
drazumijeva više identiteta združenih, kako je to inače s ljudima (Ljevak). Skupio sam različitih identiteta u svom životu, a jedan od bitnijih je moj bosanski identitet (Nikolić). I onda, neki dan šetam po gradu, a tamo kod Bezistana dvojica glasno, u hodu ogovaraju nekog trećeg, i jedan za njega kaže: „Kakav je to čovjek? Pa on ne voli ni Želju, ni Sarajevo.“ I meni je taj treći odjednom postao simpatičan, i super bi bilo da je ovdje sve više takvih kao on, koji zastupaju neki novi, „niti-ni“, baš bosanski princip... (Ljevak)

Koncept „i-i“ i/ili „niti-ni“ vlastitog identiteta Mehmedinović je ugradio i u DNK svog romana Mémed, crvena bandana i pahuljica i u smislu forme i sadržaja. Njegov roman eksperimentalno objedinjuje različite forme. Između ostaloga, Mehmedinović romaneskno objedinjuje prozu, poeziju i crteže, a unutar toga, kratku priču, crticu, feljton, mikroesej, pismo, fikcionaliziranu autobiografsku bilješku i, isto takvu, dnevničku ispovijest, kao i fikcionalizirani putopisni zapis, te lirsku pjesmu, pa i pjesmu u prozi, a onda i, uvjetno rečeno, fotografiju u lirskoj prozi, kao i kinematografski zapis. On se, također, jezično koristi fotografskim elementima u oblikovanju svog govora slika riječima, ali i svog govora slika crtežima, koji i jesu sintetski dio romana. Time svoju književnost prenosi ili prevodi u relativnu domenu vizualne umjetnosti, pri čemu je crtež transromaneskni likovni element romana Me’med, crvena bandana $i$ pahuljica. Na taj način Mehmedinović daje vizualnu materijalnost svom umjetničkom izrazu koji ispisuje i riječju i crtežom. Za sebe kaže da mu je poezija primarna vokacija, ali da poeziju ne piše godinama, već da potrebu za poezijom transformira u prozu koja ima poetske, lirske karakteristike (usp. Otvaranje V. književnog festivala Poligon). Crteži u romanu predstavljaju transformaciju književnog u likovni govor slika. Ti govori slika međusobno se dopunjuju, bilo da se na dva različita načina paralelno govori ista slika ili da se zasebnim likovnim i zasebnim književnim izrazom u jukstapoziciji objedinjuje cjelina jedne slike. U svakom slučaju crtež i riječ sinkretički su objedinjeni u romaneskni melanž. Mehmedinović objašnjava da je pisanje

zahtjevan posao, traži neusporedivu koncentraciju. Slikanje je čisto zadovoljstvo, prirodan pokret ruke nakon čega skoro istovremeno vidiš rezultat. Književnost je govor slika, i između slike u poeziji i slike u artu postoje prirodne veze, sličnosti, ali i razlike. U poeziji kreiranje slike je zahtjevan proces, tu je važan odnos između našeg unutarnjeg i vanjskog svijeta, način na koji u jeziku oblikujemo slike iz vanjskog svijeta do nas 
dolaze kao oblici, ali i obrnuti smjer kad u sliku treba prevesti određenu ideju. To prevođenje, dešifriranje, ili kako ćemo to sada zvati, taj rad u jeziku, traži preciznost, ne dopušta greške. Greška u crtežu ima ljepotu, može biti znak iskrenosti, a u tekstu ne. Ili, recimo, u tekstu opisane slike koje nikad ranije nisu viđene uglavnom djeluju kao laž, u crtežu ne, jer crtež ima materijalnost koju slika u poeziji ipak nema... (Bašić 2018: 118-119)

Mehmedinovićevo pisanje slika i crtanje zapisa u sintezi romana nikada nije izraz samo pukog gledanja, već je to uvijek iskaz pažljivog promatranja vanjskog svijeta, čija se slika prelama kroz optičku prizmu unutrašnjeg bivanja njegova književnog ,ja“ (autora i/ili njegova alterega naratora i protagonista) - njegovih misli, želja, osjećaja, sjećanja, iskustava, i to u bilježenju neposredne sadašnjosti ${ }^{9}$ kroz koju se, dakle, upravo u vidu „neprestane sadašnjosti“" ${ }^{10}$ prelama prošlost, pa i projicira budućnost. S druge strane, ta je sadašnjost često kafkijanska: „Život se polako pretvara u Kafkinu sintaksu iz koje je izostavljeno buduće vrijeme“ (Mehmedinović 2017: 117-118).

Roman Me’med, crvena bandana i pahuljica strukturalno i kompozicijski grade tri dijela koja se pojedinačno odnose na tri naslovne oznake, a sastavni dio jedino drugog dijela čine i crteži. Dio „Crvena bandana“"11 tiče se Haruna,

9 „Ja najbolje funkcioniram u sadašnjem vremenu, rado opisujem ono što mi se dogodilo neposredno nakon samog događaja. Većina pisaca traži vremensku distancu, da bi se odredilo prema nekom događaju. Imam potrebu opisati događaj skoro istovremeno, kao reakciju uživo. To mi pomaže da razumijem šta mi se događa. Tek kad iskustvo određenog događaja preselim u jezik, tek tada ga postanem svjestan. Ja pišem onda kad mi se dogodi nešto bitno, ili nešto što ja prepoznajem kao važno, nisam siguran da to događaju daje dodatnu vrijednost, ali ga učini postojećim ... Na nekom drugom, jednako tako važnom planu, napisano postoji kao lični arhiv. Bez toga, sve je podložno iščezavanju." (Bašić 2018: 113-114)

${ }^{10}$ Uz brojne druge književnike, posebno Williama Faulknera, koji su razumijevali i pisali „vječnu sadašnjost", Mehmedinović o tome, a u poveznici sa zaboravom kao svojom velikom temom, zapisuje: „Bilježim u žurbi, usput, u autu, u liftu, u krevetu, tek probuđen iz sna, jer ako istog trenutka ne zapišem, sigurno ću zaboraviti. Ali da nema tog bilježenja, da nema trenutaka u kojima se obraćam sebi, mislim da bih manje postojao, ili bih samoga sebe zaboravio.

Svaki ovaj trenutak postoji u neprestanoj sadašnjosti. I unatoč tome, svaka riječ iz ovog dnevnika jednom će biti zaboravljena. Niti će na svijetu postojati ova knjiga, niti će biti onih koji je se sjećaju. Postoje NOWS, kaže Julian Barbour, postoje različita 'sada', i sva ta 'sada' egzistiraju istovremeno, kao razne mogućnosti. I to je sve. Nitko i ništa ne putuje iz jednog 'sada' u naredno 'sada'. Mi prolazimo, a vrijeme ne. Život je prelet vrapca koji je ulepršao u kuću na jedan prozor, a izletio na drugi.“ (2017: 166)

${ }^{11}$ Bandana, bandanna, engl. - marama (prim. prev.). Crvenu bandanu/maramu nosi Harun na glavi, pa je ona u drugom dijelu romana oznaka njega. Ona je istaknuti dio sastavnih crteža toga dijela 
sina „Me’meda“, odnosno Semezdina Mehmedinovića - Sema. Upravo za Haruna i Harunu posebno je napisan drugi dio Mémeda, crvene bandane i pahuljice. Na kraju početne riječi toga dijela romana stoji:

U protekloj sedmici, na putovanju sam pisao ovaj dnevnik, koji je valjda samo meni važan. I možda bude važan tebi, jer je pisan za jednog čitaoca, za tebe. Meni je bilo bitno da nekoliko rečenica koje sam želio da ti kažem, sakrijem ovdje u mnoštvu drugih. A ti ćeš ih lako naći. Ako ih ne nađeš, to će onda značiti da ga nisi pročitao. I to je uvijek mogućnost koja stoji ispred svakog teksta: da bude nepročitan. Knjige su usamljenije od ljudi. (Mehmedinović 2017: 38)

Iako roman nije epistolaran, on ima epistolarnih elemenata, pa njegov drugi dio i počinje i relativno završava izravnim obraćanjem sinu. Naime, cijeli roman sastavljen je od crtica ili fragmenata ili dnevničkih zapisa, a prvu i pretposljednju crticu, koja, eventualno, može funkcionirati kao posljednja crtica drugog dijela, čine pisma ili dnevnički zapisi sinu. Posljednja je crtica ili fragment toga dijela, zapravo, pjesma u slobodnom stihu o transnacionalnom isječku kratkog putovanja Arizonom sa sinom koje je, na svojevrstan način, mikrokozmički simetrično njihovu obiteljskom putovanju, metaforički rečeno, kroz (trans)migrantski život u SAD-u. Ta se posljednja crtica - pjesma, između ostaloga, može shvatiti kao epilog toga dijela romana, ali i kao dio pretposljednje crtice - pisma sinu. Za razliku od ostatka drugog dijela romana gdje se isprepliće drugo lice izravnog i treće lice neizravnog obraćanja sinu koje i prevladava, u prvom i (pret)posljednjem zapisu, isključujući pjesmu u uvjetnom epilogu, obraćanje sinu je izravno. Paralelno epiloškoj mogućnosti karakteristike posljednje crtice ili zapisa u stihovima toga dijela romana, prva crtica ili zapis može funkcionirati i kao epigraf ili uvod „Crvene bandane“. Tu se, također, povezuje priča prvog i drugog dijela Me'meda, crvene bandane i pahuljice. Osim toga, prvom i (pret)posljednjom crticom, fragmentom ili dnevničkim zapisom simetrično se uokviruje sadržaj zapisa tekstom i crtežom drugog dijela romana, s tim da

romana, kao i lajtmotiv slikā ispisanih jezikom: „Crvena bandana. Moja nena, a njegova prabaka, nosila je istu takvu šamiju na glavi. Njena je marama bila bijela, ali je, čini mi se, imala iste šare kao i bandana na glavi mog sina“ (Mehmedinović 2017: 39). „Mislio sam da je crvena bandana tvoja fotografska uniforma. Jesmo li mi u Bosni govorili ‘bandana'? Ili su različite vrste 'marame’ imale jedan, zajednički nazivnik? Ne sjećam se. Počeo sam zaboravljati svoj jezik“ (Mehmedinović 2017: 85). Harunu crvena marama nije radna uniforma u vidu teatarskog efekta i vida ulaženja u ulogu fotografa. On kaže: „Ja maramom pokrivam kosu da mi ne smeta dok snimam. Ili je natopim vodom da rashladim vrat u pustinji.“ (Mehmedinović 2017: 86) 
su prvi i posljednji zapis „Crvene bandane“ ispisani samo prozno-poetskim / poetsko-proznim pismom. Između njih, odnosno, unutar drugog dijela romana, priča/slika crteža dopunjava priču/sliku jezika, i obratno, bilo da se na ta dva načina paralelno ispisuje i iscrtava ista priča/slika ili da se tekstom jezika i tekstom crteža fragmentarno sastavlja jedna priča/slika. U svakom slučaju povezivanje slika pisanim i crtanim tekstom ili, drugim riječima, povezivanje teksta jezičnom i crtanom slikom u drugom dijelu romana ostvaruje se, relativno i uvjetno rečeno, (trans)književnom ili, preciznije, transromanesknom metodom time-lapse. U sva tri zasebna, ali riznički, dnevnički, pa i albumski spojena dijela romana u vlastitu i obiteljsku memoarsku priču, fragmenti ili crtice ili dnevnički zapisi rizomski se povezuju na principu metonimijskih asocijacija, kojima se, također, ostvaruje i neprestana sadašnjost, pa tako i time-lapse prošle i sadašnje sadašnjosti u njihovoj jukstapoziciji. Crteži priču čine više živom i uvjerljivom. Istovremeno, a za razliku od fotografije kojom se „dokumentira postojanje, iako uvijek zapravo pokazuje nešto što više ne postoji“ (Mehmedinović 2017: 84-85), crtež „nema snagu dokumenta, crtež je nepouzdan kad se uspoređuje sa stvarnošću koja se vidi golim okom“ (Mehmedinović 2017: 85). Zbog toga pisac i/ ili njegov književni alterego kaže da crtež fikcionalizira njegove zabilješke na putu, i dodaje: „ta nepouzdanost dobro opisuje moje putovanje s Harunom, zato što mi se ovih dana prošlost opasno izmiješala sa sadašnjošću“ (Mehmedinović 2017: 85). Međutim, i slike crteža i slike književnog teksta u romanu imaju obilježje uspješne fotografije na način kako se fotografija kao takva obrazlaže upravo u drugom dijelu romana: „Uspješna je ona fotografija - parafraziram Barthesa ('Camera Lucida') - na kojoj jedan detalj, 'punctum', ima magnetičnost zbog koje se fotografiji iznova vraćamo“" (Mehmedinović 2017: 70), i gdje se za primjer „punctuma“ daje očigledna simetrija određenih detalja na (uspješnoj) fotografiji. Također, slike crteža posebno, ali i slike fragmenata teksta urađene su (i) tehnikom Colour Correction (Bašić 2018: 115), što predstavlja „izoštravanje boja u slici ili videu“ (Bašić 2018: 115) s ciljem pojačavanja dojma. Na crtežima koji se nalaze, dakle, samo u drugom dijelu romana bojama su izoštreni određeni detalji. U tekstu cijelog romana na principu lirskih paralelizama pojačan je dojam određenih detalja, dok su jedino u drugom dijelu romana istaknuti i određeni paralelni detalji na crtežu i u jeziku teksta. Sve to u cjelini doprinosi stvarnosnoj uvjerljivosti priče. Osim toga, sve su to i načini dokidanja granica između umjetničkih medija i proširenja konceptualne ideje u književnosti. 
Mehmedinović sam često ističe svoju sklonost konceptualnoj umjetnosti (usp. Otvaranje V. književnog festivala Poligon i Bašić 2018: 113). Iz toga, kako kaže, uz ostale razloge, proizlazi i njegovo pisanje jednoj osobi, jednom čitatelju. Dodaje: „Napisati knjigu za jednog čitaoca izriče jednostavan stav. Na taj način se jednaka važnost daje autoru i čitaocu, stavlja ih se u istu ravan. Knjiga tada doslovno biva komunikacija između dvije osobe, dvije ravnopravne samoće" (Bašić 2018: 113). Drugi dio romana, „Crvenu bandanu“, pisao je za sina jer iza toga dijela romana stoji „grižnja savjesti. Otac si ne može oprostiti to što je sina, tada dječaka u najosjetljivijim godinama, zadržao sve vrijeme rata u Sarajevu. Razlozi su, naravno, idealistički“ (Jergović). Otac se u romanu na asocijativno-metonimijskom principu vraća unazad i rekonstruira slike sjećanja na sarajevski život u vrijeme opsade. Iz poslijeratnog pogleda „naknadne, emigrantske i američke perspektive“" (Jergović) na preživljeni rat sa sinom i suprugom u Sarajevu, ali u neprestanom bivanju svih tih sadašnjosti - i davnih i neposrednih - on osjeća krivnju kao sizifovski teret. Ona istinski i iznad svega proizlazi iz ljubavi, ali i znanja zasnovanog ponajprije na iskustvu rata i traume koji su pohranjeni u sjećanjima, što je sveukupno u slučaju Me’meda, crvene bandane i pahuljice neraskidivo povezano. Prema Freudu odnos prema traumi razrješava se upravo na „razini sjećanja“ (usp. Mijatović 2009: 156). Znanje ratne, a onda i poslijeratne i/ili emigrantsko-imigrantske traume koje u područje svijesti donose sjećanja u romanu se reflektira kao freudovska „memorija iza zaslona“ („screen memory“), pa to znanje uzrokuje „Me’medovu“ bol, krivnju i osjećaj gubitka i na osobnoj i na obiteljskoj razini („Troje, mi smo plural, ali svejedno u ogledalu smo odraz čiste samoće“) (Mehmedinović 2017: 124). Svo troje na svojstven vlastiti način dijele istu povijest - povijest kao traumu. Kako to ističe Cathy Caruth, povijest je upravo način na koji smo međusobno upleteni u traume drugih (usp. 1996: 24). Krivnju i odgovornost, također, autor / pripovjedač / protagonist osjeća za sve što se dogodilo njegovoj supruzi. Njoj je pisao i napisao treći dio romana, „Pahuljicu“. O tome veli: „Supruga je imala moždani udar i posljedica je bila gubitak pamćenja. Da bih joj formirao sjećanja, bilježio sam svakodnevno šta se događa“ (Otvaranje V. književnog festivala Poligon). „Pahuljica“ je najduži dio romana. Za njega Miljenko Jergović kaže da je najšokantniji. To je selimovićevska „ljubavna priča“ (Jergović) („Nevolja nas je svela na suštinu. I ništa više od nas nije ostalo, osim ljubavi“) (Mehmedinović 2017: 173) u Mehmedinovićevu ključu, čija istovremena jednostavnost i kompleksnost sadrži, između ostaloga, potragu „za izgubljenim sjećanjima, koja su važnija njemu koji pamti, nego njoj koja je zaboravljala“ (Jergović). U 
prvom dijelu romana, „Me’med“, bilježio je, također, iz neposredne sadašnjosti ono što se njemu događalo nakon preživljavanja srčanog udara i suočavanja s mogućnošću gubitka pamćenja kao posljedice lijeka čije mu je korištenje bilo prepisano da bi spriječilo novi srčani udar. Stoga se može shvatiti i reći da je prvi dio romana pisao za sebe kao svog idealnog čitatelja, pri čemu je taj „on“ koji se udvaja, umnožava i rascjepljuje, dok je njegova množina istovremeno i jednina, i/ili autor i/ili narator i/ili protagonist i/ili čitatelj. On je „Me’med“ jer

Kada se pacijent s akutnim infraktom, imena Semezdin Mehmedinović, pojavljuje na bolesničkom stolu, liječnik, Amerikanac, treba ime, šifru, način na koji će mu se tokom procedure obraćati. Kako mu je Semezdin Mehmedinović neizgovorivo, on će ga zvati Me'med, i to biva njegovo bolesničko ime, ali, na određen način, i kod nekoga sasvim novog identiteta, identiteta srčanog bolesnika i Amerikanca [ali i „Drugog“ i drugačijeg]. Iako je prije infrakta već petnaestak godina živio u Sjedinjenim Državama, neizgovorivost njegova imena i prezimena tek je sada postala važnom, gotovo sudbinskom temom. Ono što se u ovom slučaju tiče tek funkcioniranja živog organizma, kardiovaskularnog incidenta i čovjekove intime, već u sljedećem trenutku može se ticati društva u cjelini, političkih prilika u zemlji, tobožnje borbe protiv terorizma praćene sumnjičenjem, a onda i hajkom na ljude neizgovorivih imena i prezimena. Liječnik koji savjesno obavlja svoj posao i spašava čovjeku život, ne čini ništa loše kad zanemaruje svaku političku korektnost i odbacuje neizgovorivo ime i prezime. Ono ga dekoncentrira i ne može ga nabrzinu smrsiti. Ako bi ustrajao na poštovanju osobe i njezina građanskog i kulturnog identiteta, doveo bi u opasnost njezin život. A cilj je kardiologov spašavati život, a o drugome ćemo nakon što srce nastavi normalno da kuca. Društvo, međutim, i država, nemaju izliku kardiologa. Jedno je totalitarni režim bolnice, a drugo totalitarni režim države. Totalitarizam klinike je nužnost, ali drama započinje kada se država pretvori u kliniku. (Jergović)

Ime ${ }^{12}$ „Me’med“, osim toga, simbolizira mogućnost smrti identiteta (pri čemu je dio zbira toga identiteta, između ostalih, i imigrantski, čiju univerzalnu sim-

12 „Ja ću te zvati Me’med“ (Mehmedinović 2017: 15) podsjeća na izjavu Ishmaela iz romana Hermana Melvillea Moby Dick, koji o samom sebi u jednoj od najpoznatijih ikad napisanih prvih rečenica jedne knjige, „Zovite me Ishmael“, biblijsko-simbolički kaže da se smatra siročetom, a time i osobom uskraćenog i oduzetog identiteta - osobom bez identiteta, s razlikom da ime „Me’med“ biva dano osobi kojoj se time istovremeno oduzima vlastito ime i osobnost. „Me’med“ je kôd, simbol i, ujedno, figura imigranta, američkog i univerzalnog. 
boliku sažima upravo ime/novanje „Me’med/om“) i strah od njegova zaborava („Ako zaboravim sve, cijeli svoj život, ako ne mogu prepoznati lice svog djeteta, ako i vlastito ime zaboravim, zar to nije isto što i smrt?") (Mehmedinović 2017: 37). Iz tog razloga Semezdin Mehmedinović / „Me’med“ ispisuje taj dio romana posebno i ponajprije zbog rekonstrukcije i očuvanja svojih sjećanja nasuprot zaboravu i smrti. Zaborav je upravo opsesivna tema Me'meda, crvene bandane i pahuljice i, inače, Semezdina Mehmedinovića, kako to i sam tvrdi (Otvaranje V. književnog festivala Poligon). Također, tema zaborava je okosnica strukture romana za koju Mehmedinović objašnjava da ju je

tako uredio život. U novembru 2010. meni se dogodila nezgoda sa srcem i ja sam je opisao u tekstu Memed koji sam pisao, manje više, u vrijeme kad se sve i događalo. Ja tako pišem, iz sadašnjeg vremena, posmatrajući ono što mi se događa. Na neki način to je odbrambeni metod: posmatram što mi se događa i to opisujem kao da se događa drugome. Tako je lakše proći kroz tragičko iskustvo, mislim. Ja nisam imao jasnu ideju šta s tim tekstom da radim, objavio sam ga na Jergovićevom online magazinu Ajfelov most. Poslije je tekst preveden na engleski i objavljen u časopisu Granta, reakcije su bile odlične, pa je priključen i u antologiju Best European Fiction 2013. Tek u proljeće 2015. g. ja sam imao putovanje u Phoenix, i susret sa sinom sam opisao u Crvenoj bandani. To je bio tekst napisan za njega kao jedinog čitaoca. Ja priznajem da Crvenu bandanu nisam povezivao s Memedom, premda sam bio svjestan njihove povezanosti. Dakle, u tom trenutku, ja nisam imao ideju knjige koja ih smješta između istih korica. Godinu dana kasnije, ono što se dogodilo mojoj supruzi, i činjenica da je ona za posljedicu svoje bolesti imala memory loss, dakle, činjenica zaborava povezala je ta tri teksta. Struktura knjige slijedi događaje u vremenskom kontinuitetu jer je tako, činilo mi se, prirodno, događaji se prirodno nastavljaju, jedan drugi, na neki način, uzrokuju. Taj kontinuitet događaja temelj je prirodne romaneskne strukture... (Mehmedinović Re: Pitanje zbog naučnog rada $)^{13}$

Roman Me'med, crvena bandana i pahuljica u cjelini je svojevrsna konceptualno-(književno)umjetnička radionica sjećanja - „Me’medovih“, „Crvene bandane“, „Pahuljice“, kao i njihovih obiteljskih u relativnom anti/mimetičkom ${ }^{14}$

\footnotetext{
${ }^{13}$ Isticanje podvučenog S. R.
} 
registru autora / naratora / protagonista, a onda i njihova životnog vremena i prostora svih njihovih sadašnjosti, u cjelini i pojedinačno pretočenih u tekst nove književno-umjetničke prakse i izraza kao mjesta pamćenja i mjesta života. Pamćenje i jest fenomen suprotan zaboravu. U romanu je, kao i u životu, pamćenje fragmentarno. Romanom se pamćenje promatra, a promatranje znači „tumačenje, znači poeziju“ (Đorđević). Ono se bilježenjem poetizira. Unutar antimimetičkog registra, autor / narator / protagonist bilježi vlastiti mimetički registar i, posebno u „Pahuljici“, suprugin mimetički registar iz svoje vizure koji je, istovremeno, i njegov („Ja o njoj govorim u pluralu, umjesto ona kažem mi. Sebe sam poistovjetio s njenim stanjem.") (Mehmedinović 2017: 162). Osim odnosa prema traumi na razini sjećanja i svijesti, u romanu se trauma iskustveno događa i razrješava i na „razini tijela koje se ne brani od šoka, nego ga pounutrujući oponaša“, pri čemu se književni subjekt približava šoku i time izvlači iz sebe samoga (usp. Mijatović 2009: 156). Prema tome, antimimetički je registar istovremeno i mimetički jer distanciranost od događaja (anti-mimetički registar) moguća je samo pod cijenu distanciranosti od samog sebe (mimetički registar) (Mijatović 2009: 156). Ispisivanjem poetike prostora romana, uključujući i njezino iscrtavanje, sjećanje različitih razina prošlosti i poimanje vremena događaju se zajedno u međusobnom odnosu iskustva, percepcije, znanja i sjećanja, kao i svjesnog i nesvjesnog. U parafrazi riječi Juliusa Laffala (usp. 1964: 173) i Cathy Caruth (usp. 1996: 3), sve se to u Me'medu, crvenoj bandani i pahuljici susreće u jeziku kao čvorišnom fenomenu koji spaja „znati“ i „ne znati“. Zbog svega toga, tekst romana je i arhiv prošlosti u izrazu umjetnosti sjećanja. S druge strane, „tekst prestaje biti knjiga, već stvarnost sama po sebi“ (Otvaranje V. književnog festivala Poligon). Jergović zapisuje:

Ovo je roman o porodici, o mužu, ženi i sinu, roman o emigraciji, o nizu emigrantskih samoća, Americi onakvoj kakva ona jest i kakvom se do-

oponašanja i identifikacije zbog čega se žrtva ne može sjećati traumatičnoga događaja, već jedino oponašati. Traumatski doživljaj potresa žrtvine psihološke mehanizme zbog čega takav doživljaj nikad ne može postati dijelom sjećanja. Ali, kako upozorava Lays, ako žrtva ne može traumatski doživljaj uklopiti u sjećanje, tada to potkopava istinitost njezina svjedočenja. Nasuprot mimetičkom uranjanju žrtve u traumatski doživljaj, antimimetička teorija podrazumijeva da se subjekt distancira od traumatskog doživljaja. Subjekt se u tom činu distanciranja podvaja na promatrano i promatrača traumatskog prizora, pa prema antimimetičkom poimanju, žrtva može prenijeti traumatski doživljaj drugome." (Mijatović 2009: 150) Mijatović, također, objašnjava da mimetički registar vezanosti za traumu podrazumijeva stanje „ponavljanja traumatskoga doživljaja“, a „antimimetički registar sjećanja kroz koje se“ osoba „razvezuje od traume“ podrazumijeva „stanje sjećanja“ na traumatski doživljaj (usp. Mijatović 2009: 153). 
življava kroz iskustvo nekoga tko se sedamdesetih i osamdesetih godina živeći u Sarajevu i u Jugoslaviji formirao kroz američku kulturu. Ali ovo je i prvi roman o Trumpovoj Americi, ili o polaganom rađanju Trumpove Amerike kroz naljepnicu šovinističkog sadržaja na plavom Fordovom kamionetu u nekoj zabiti Arizone... Ova knjiga potvrđuje kako se kroz govor o najintimnijim činjenicama čovjekova života izriču posljednje istine o društvenoj zajednici, koje uključuju i najsvježiji dnevni društveno-politički izvještaj.

Svijet, isto kao i čovjek u njemu, na određeni se način u romanu vide kao ruševina. Minuciozni fragmenti neprestane sadašnjosti u spoju i pokretu različitih, vremenski dalekih i bližih, te osobnih, obiteljskih i društvenih sadašnjosti „Me’meda“, „Crvene bandane“ i „Pahuljice“, kao i, također, minijaturne slike pokretne sadašnjosti svijesti i podsvijesti u spoju njezina doživljaja autorovim / naratorovim / protagonistovim viđenjem i, rjeđe, snoviđenjem nisu krhotine cjeline, niti je sve to nepovezivo, već je ta neprestana sadašnjost ruševina koju promatrački subjekt „tek mora (raz)graditi iz dijelova cjeline. Današnjica od nas ne zahtijeva da gradimo neku cjelinu bez ijedne napukline, već da iz cjeline tek rekonstruiramo ruševinu. Mi ne rekonstruiramo cjelinu, već obnavljamo ruševinu“" (Mijatović 2009: 160). Početak rušenja svijeta promatračkog subjekta i, ujedno, njega samoga je 1992. godina. Iz te godine u svojoj prošlosti, kada je počeo rat u Bosni i Hercegovini, on kaže da nikada nije izašao (usp. Mehmedinović 2017: 27). Bilježenje svoje neprestane sadašanjosti, prema tome, ima i katarzičnu funkciju. Upravo je jedna od funkcija umjetnosti, prema Freudu, da „služi fiktivnom razrješenju unutarnjih napetosti između podsvjesnih poticaja i svjesne djelatnosti pojedinaca, jer ona u simboličkom obliku predstavlja i tako na neki način osvješćuje primarne ljudske nagone“ (qtd. u Solar 1991: 229). Stoga je Memed, crvena bandana i pahuljica izraz i umjetnosti traume, umjetnosti neizrecivog, a time i kritike (post)traumatske zbilje. Roman Semezdina Mehmedinovića je, između ostaloga, fikcionalizirana (auto)biografska ispovijest čovjeka kao ruševine i konceptulano-književna kronika svijeta, također, kao ruševine, a time i života kao ruševine. Sve se te ruševine unutar umjetnosti i izvan nje umjetnošću obnavljaju. Osim toga, ruševine čovjeka, svijeta, života i pojedinca i „Zamišljenih zajednica“ (Anderson 1998: 22) u romanu se vremenski kontekstualiziraju, s tim da imaju i univerzalnu dimenziju. Sarajevska opsada i doba rata u Bosni i Hercegovini čine točku vremena traume i apokalipse u odnosu na koju se vrijeme Mémeda, crvene bandane i pahuljice dijeli na prije i poslije. 
To je vrijeme razine svijesti romana. Također, tri dijela romana imaju i svoje kronološko vrijeme kojim se strukturno i dijakronijski povezuje neprestana sadašnjost niza fragmentiranih sinkronija teksta romana u jednu cjelinu. Prvi dio, „Me’med“, počinje u „utorak, 2. novembra 2010. godine“ (Mehmedinović 2017: 17), kada romaneskni subjekt koji promatra, odnosno bilježi sebe, doživljava srčani udar. Taj je klinički traumatski događaj/doživljaj na razini tijela u interpretaciji razine svijesti okosnica toga dijela romana i njegova vremena. Drugi dio, "Crvena bandana“, događa se u proljeće $2015 .{ }^{15}$ kada taj isti subjekt odlazi na putovanje Arizonom sa svojim sinom fotografom, na kojemu se on bavi snimanjem noćnog neba iznad pustinje. To je putovanje istovremeno odiseja u prošlost glavnog subjekta tragom sjećanja na doživljeno i proživljeno u odupiranju zaboravu. Također, ta odiseja predstavlja iskonsku potragu za vlastitim identitetom. Treći dio, „Pahuljica“, paralelno prvom, počinje kada subjektova supruga doživljava moždani udar, 2. travnja 2016., što je traumatska okosnica toga dijela romana i njegova vremena. On bilježi i vlastito pounutrenje suprugina klinički traumatskog događaja na razini njezina tijela, što je, također, klinički povezano s njezinom svijesti u smislu gubitka njezinih fragmenata. Bilježenjem i pounutrenjem njezin se doživljaj preobražava i u njegov. Na taj se način trauma na razini njezina tijela i njezina odraza na njezinu svijest, ponajprije u njegovu promatranju i iskustvu jer ona svoje zaboravlja zbog suočavanja s gubitkom pamćenja uzrokovanim moždanim udarom, isprepliće s traumom na razini svijesti i, ponovo, iskonskom potragom za vlastitim identitetom. Time traume na kojima se temelje prvi i treći dio romana posebno, zasebno i zajedno jesu i „klinički koncept koji se odnosi na iskustvo povrede / ozljede / oštećenja (injury) i kultu-

\footnotetext{
${ }^{15} \mathrm{Na}$ put kreće 16. travnja 2015., dva dana nakon rutinskog polugodišnjeg pregleda kod doktora, na kojemu liječniku izražava želju da se, kako to sam bilježi, oslobodi lijeka koji uzima već skoro pet godina i koji ga umara i usporava. Međutim, liječnik mu to ne dopušta jer je funkcija lijeka da spriječi novi srčani udar, te naglašava da su prateće posljedice lijeka, poput gubitka pamćenja, „bezazlene u poređenju s njegovim pozitivnim djelovanjem“" (Mehmedinović 2017: 37) na organizam. Uslijed toga javlja se strah subjekta od zaborava svoga identiteta, odnosno smrti identiteta. Promatrački subjekt promatra sebe $s$ vremenskim odmakom od sebe promatranog od jednog tjedna u prvom zapisu drugog dijela romana i bilježi u dnevničkom pismu sinu: „Nakon pregleda, vozeći se kući, mislio sam - šta ako sam već počeo zaboravljati? Tražio sam znakove svoje zaboravnosti. Ali - koliki je moj zaborav? To se ne može izmjeriti. Ono što je zaboravljeno, to je sada nedostupno jer je nevidljivo, jer je u 'mraku zaborava'. Osjetio sam tada potrebu da budem u društvu neke osobe, $s$ kojom sam dijelio puno zajedničkog vremena u prošlosti, i da uspoređujemo svoja sjećanja na iste događaje. Tražio sam način da se vratim u vlastitu prošlost i onda sam, istog dana, kupio avionsku kartu za Arizonu. A možda je razgovor s ljekarom bio samo izgovor za nešto što se već godinama spremam - otići da još jednom vidim naš stan u Phoenixu, našu prvu američku adresu." (Mehmedinović 2017: 37-38)
} 
ralni trop koji ustanovljuje tumačenje kao način nošenja s traumom kroz proces njezine simboličke interpretacije" (Mijatović 2009: 144). Dva na svojstven način paralelna traumatska događaja/doživljaja „Me’meda“ i „Pahuljice“ „uslijed svoje preobrazbe u figuru“ (Mijatović 2009: 144) (trauma kao kulturalni trop) interpretacijom postaju sastavni dio ličnosti promatračkog subjekta koji iz relativno odmaknute posttraumatske pozicije promatra sebe u traumatskoj poziciji. On sam sebi interpretira ta dva traumatična iskustva i usporedo ih prevodi s engleskog jezika, u kojemu mu se događaju, na svoj materinski. Za razliku od toga, trauma razine svijesti i memorije romana, kao i njegova glavnog subjekta $\mathrm{u}$ (p)odvojenosti, ali i jedinstvu instanci autor / narator / protagonist, koja se tiče iskustva rata, dogodila se u subjektovu materinskom jeziku. Osim toga, kulturalni trop ili figura ratnog traumatskog iskustva sastavni je dio i osobnog psihičkog i kolektivnog društvenog ustroja svijeta romanesknog subjekta. Međutim, sva tri traumatska iskustva svojevrsna su "granična iskustva“16 života i svijeta romanesknog subjekta jer prelamaju njegovo vlastito bivanje na vrijeme prije i vrijeme nakon svakog tog pojedinačnog iskustva. I sva tri se, također, tiču, njegove obitelji. Prema tome, pripovijedanje se u Mémedu, crvenoj bandani $i$ pahuljici oslanja na doživljeno i proživljeno, a u tome i preživljeno, te relativno i na sanjano i željeno, što je opet povezano s tumačenjem, odnosno poetikom doživljenog i proživljenog. Takva se poetika oslanja „na istinu, koja se ukoliko je riječ o umjetničkom djelu, nužno mora dopuniti fikcijom, pri čemu ova, ukoliko je djelo uspjelo, uvijek stoji u službi istine“ (Đorđević).

Granično iskustvo autora / naratora / protagonista romana i njegove obitelji je i iskustvo njihova emigrantskog dolaska u Ameriku.

Kad smo na ovaj aerodrom sletjeli prvi put, 1. februara 1996. godine, $s$ nama nije stigao naš prtljag. Izgubio se negdje usput. Aerodromski službenik je rekao da to nije problem i da će naš kofer, čim ga pronađu, proslijediti na našu adresu. Ali mi tada adresu nismo imali. Prtljag je izgubljen i to me je ispunilo neopisivom tjeskobom. Poslije će se ispostaviti - sadržaj našeg kofera bio je sasvim nebitan: nešto zimske odjeće koja nam u pustinji neće trebati, i knjige koje ponovo, vrlo vjerovatno, nećemo čitati. Ali izbjeglima iz rata taj kofer je bio sav posjed, on je bio naše sve. (Mehmedinović 2017: 40)

16 „Događaj koji se ne uklapa u zamisao o kontinuitetu povijesti ne može se objasniti ničim do tada poznatim pa se proglašava graničnim jer prelama povijest na vrijeme prije i vrijeme nakon njega." 
Mehmedinovićev se roman na različite načine i na više diskurzivnih razina od samoga početka bavi pitanjem: „ko sam?“ (Mehmedinović 2017: 13), pitanjem identiteta književnog subjekta u rascjepu i spoju instanci protagonista, naratora i samog autora. Jedan od identiteta i književnog subjekta i romana je transnacionalni. Taj je identitet istovremeno, između ostaloga, marginalan, egzilantski, (trans)migrantski, transetnički, transreligijski, liminalan, pluralan, transgraničan, „drugačiji“ - identitet „Drugoga“, pa time i hibridan, a u svemu tome originalan. On je višenacionalan, a zapravo nadnacionalan i nenacionalan. Književni subjekt rođen je i živio u bivšoj Jugoslaviji, u dijelu sadašnje države Bosne i Hercegovine. U Sarajevu je preživio rat zajedno sa suprugom Sanjom i sinom Harunom, tada malim djetetom. Tek je pred kraj sarajevske opsade iz rata, Sarajeva i Bosne i Hercegovine prva otišla supruga sa sinom, ${ }^{17}$ a nedugo zatim pridružio im se i on. ${ }^{18}$ Roman $(\mathrm{mu})$ se vremenski i prostorno fizički događa u Americi, ${ }^{19}$ ali (mu) se njegov kronotop u transmigrantskom spoju življenja i bivanja događa uporedo na razini tijela i na razini (pod)svijesti u svim vremenima i prostorima njegova ${ }^{20}$ života, prevladavajući i nadilazeći njihove granice. Tekst romana fragmentarno rekonstruira ruševine neprestane sadašnjosti preko granica koje predstavlja nacija - država i svoj identitet razvija $\mathrm{u}$ istovremenoj poveznici američke i bosanskohercegovačke kulture, društva i nacije. Pri tome on propituje i zasebne konstrukcije američkog i bosanskohercegovačkog identiteta na razini vlastitih i kolektivnih odrednica pojedinačno i u njihovu međusobnom odnosu, također. Propituju se, nadilaze i prevladavaju dimenzije američkog nacionalnog identiteta kao koncepta „čistog“ identiteta s obzirom na, metaforički, ali i činjenično rečeno, imigrantsku DNK SAD-a, kao i dimenzije bosanskohercegovačkog, te ex-jugoslavenskog i postjugoslavenskog, a onda i južnoslavenskog i istočnoeuropskog identiteta preko granica „zamišljenih zajednica“. Romanom se ističe američki, ali i postjugoslavenski, a onda i

17 „Iz Sarajeva je s Harunom izašla u septembru 1995. godine. Grad je još bio pod opsadom, vozač iz Sorosha vozio ih je preko aerodromske piste, do Konjica, a tamo su se ukrcali u neki kamion i tako stigli do Splita. Dva dana su prošla prije nego što sam se čuo s njima, već su bili u kući mojih zagrebačkih poznanika Nenada i Marije s kojima se Sanja tada prvi put srela. U kratkom telefonskome razgovoru, rekla mi je da su ona i Harun dobro, da je put bio iscrpljujući i da se odmaraju. I rekla je da su Nenad i Marija dobri ljudi. Pitao sam je - 'Kako znaš?' A ona je odgovorila - 'Zato što u njihovoj kući mačka i pas žive skupa."“ (Mehmedinović 2017: 169-170)

18 „... u vrijeme opsade, nekoliko sam puta izlazio iz grada kroz tajni tunel ispod piste, i vraćao se, a na kraju sam preko iste aerodromske piste i otišao, možda zauvijek. " (Mehmedinović 2017: 90)

${ }_{19}$ Prva oznaka kojom se odmah na početku romana označava događanje njegove (fizičke) radnje u Americi je pozivanje pomoći hitnih službi na broj „911“ (Mehmedinović 2017: 9).

${ }^{20}$ I romana i književnog subjekta. 
univerzalni stvarnosni apsurd „Drugosti“, pri čemu se ispisuje „Drugost“ „Dru-

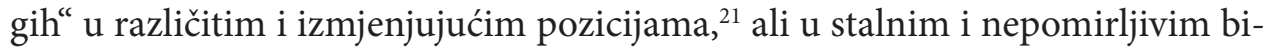
narnim opozicijama. Književni subjekt je sam(o) čovjek koji je uvijek kao takav na margini. S margine društva zapisuje na putovanju sa sinom i ovo:

Parking ispred hotela je prazan, a na recepciji mladi Navajo tvrdi da su sve sobe zauzete osim neke specijalne koja košta 380 dolara noć. Nemoguće! To je nepristojno skupo, kažem. Parking je prazan, ali on tvrdi da je to jedina slobodna soba. Ne može biti da ovaj dječak mene kažnjava zato što sam u njegovim očima bijeli muškarac, turist na njegovoj zemlji. „Mladiću, već dvije noći nisam spavao, hotel je prazan, a ja želim samo krevet da u njemu sklopim oči!“ On vrti glavom, nema praznog kreveta. Nemoguće je da me on tako vidi, i da me zbog toga kažnjava. I onda kažem - „Look at me young man! Pogledaj me pažljivo: I am not white!“ Privučeni našim razgovorom, iza njegovih leđa počinju da se skupljaju hotelski radnici i zbunjeno se smješkaju. Izađem napolje. Ali, kako drugačije da to kažem? Nisam ja bijelac! Uvijek, i na svakom kontinentu, ja sam ugrožena manjina. Za Evropljane musliman. Za Azijate Evropljanin. Za Amerikance... Nekoliko puta ovdje mi je rečeno - „Go back to Russia!“, a to spada u najblaže identitetsko prekoravanje. Zašto meni uporno stižu kazne zbog tuđih grijeha? Uvijek na brisanom prostoru, bez zaklona, unaprijed spreman na udarce. A ja repove svih granata koje su padale na kuće u kojima sam stanovao nosim sa sobom, kao potvrdu preživljavanja, i kao upozorenje. To je bio brzi, i kratki, napad samosažaljenja. A imam li ja ovdje pravo na samosažaljenje?

Već dvije noći nisam spavao, napolju pada sitna kiša, tužniji sam puno više nego što sam to spreman priznati. Mi smo u pustinji koja spada u tzv. high desert, i hladno je. (Mehmedinović 2017: 54)

Neminovno se nameće zapažanje da je svijet kao takav (ne samo Amerika) pustinja, eliotovska "pusta zemlja“ s kojom se suočava čovjek u Mehmedinovićevu romanu, a onda i njegov konceptualno-književni zapis, možda, da bi je

\footnotetext{
${ }^{21}$ Naprimjer, društveno marginalizirani kao „Drugi“, u ulozi žrtve čiji koncept žive kao jedinu istinu, pa time postaju i žrtve samih sebe, sve one koji ne pripadaju tom istom konceptu identiteta, vide kao „Druge“, pa i dalje grade i njeguju odnos binarnih opozicija „Mi“ naspram „Oni“. Takav je, recimo, lik medicinskog tehničara koji se imenuje kao mladi Afrikanac i koji zbog pogrešnog shvaćanja jedne situacije s književnim subjektom, kojega vidi kao bijelca, automatski pomišlja da je on rasist (usp. Mehmedinović 2017: 22-24).
} 
zalio i natjerao „da procvate kao ruža“ (Radeljković 2004: 77). Međutim, tekst romana nije utopijski, a ni to zalijevanje pustinje nema kolektivni priziv. Ono se odnosi na pojedinca. Također, pustinja se može čitati i samo kao pustinja. Boraveći u istinskoj pustinji, književni subjekt bilježi:

Nisam znao da je pustinja ovako lijepa. Mi sebi rado postavljamo metafizička pitanja o svijetu, životu i čovjeku. A trebali bismo stalno i iznova pitati: zašto s tolikim naporom i mukom živimo, kad znamo da ćemo ovdje biti samo jednom i kad imamo tako kratko i neponovljivo vrijeme u ovom neopisivo lijepome svijetu. (Mehmedinović 2017: 53)

U njemu je on, kako sam zapisuje, stranac svuda i čim pređe preko kućnog praga, zakorači „u ambis“ (Mehmedinović 2017: 69). Međutim, on nije samo (ontološki) stranac, imigrant, marginalizirani pojedinac neizgovorivog ili teško izgovorivog, „drugačijeg“ imena, „Me’med“ ili „Sem Memedinovik“ (Mehmedinović 2017: 167). „Sem“ mu je nadimak kojim ga zove i sin, kada ga, prelaskom u engleski jezik ne oslovljala formalno ili, nekad, kada ga u razgovoru sa svojim američkim poznanicima ne nazove my dad (Mehmedinović 2017: 78). On je i čovjek koji cijeli život nosi „teret svoga imena bez značenja“ (Mehmedinović 2017: 104). Bilježi dajdžinu vjerojatno izmišljenu priču i objašnjenje o porijeklu imena Semezdin da je „nastalo iz čerkeske nostalgije za mjestom porijekla“ (Mehmedinović 2017: 146). ${ }^{22}$ Iako ne vjeruje u dajdžinu priču, simbolika značenja njegova imena, kao i odnos te oznake i označenog, dio su identiteta književnog subjekta i romana. Tek se u svojoj 56. godini, na određeni dan, izmirio i poistovjetio s imenom zbog svoje supruge i njezine, odnosno njihove ljubavi.

Ljekar je pita: Koja je ovo godina? Koji je mjesec? Gdje smo sada? Ona ga gleda i nema odgovora, ona je zaboravila godinu i mjesec i mjesto. A onda ljekar pokaže rukom na mene koji sjedim do njenog kreveta - „A ko je ovaj čovjek?“ Jedan trenutak je umirivala pogled, činilo mi se da gleda kroz mene, i lijepo sam osjetio studen što kroz moje tijelo prolazi. I mislio sam, ona me je zaboravila. Ali onda je njeno lice u trenutku doživjelo transformaciju, gledala je u mene kao da me je spasila iz nepostojanja, ili kao da me je upravo rodila, i s izrazom najčistije ljubavi rekla - „Semez-

${ }^{22}$ Dodatno, književni subjekt daje vlatitu definiciju nostalgije: „... nostalgija je osjećanje koje povezujem s konkretnim vremenom: u kasnom dječaštvu, u onom osjetljivom adolescentskom dobu, mi ispred sebe imamo beskonačan broj puteva, a nekoliko godina kasnije, kad se svojim izborom svedemo na onaj jedan, javlja se čežnja za vremenom u kojem smo mogli birati između velikoga broja različitih mogućnosti. To je meni nostalgija." (Mehmedinović 2017: 42-43) 
din, moj." I to je bio tren u kojem se moje ime ispunilo značenjem. Ja sam Semezdin, njen. To je moja ljubavna priča, i sav moj život. (Mehmedinović 2017: 105)

Ona je „Pahuljica“ na osnovu njegova viđenja i doživljaja njezina lika zabilježenog u bijeloj ljetnoj haljini do članaka na staroj crno-bijeloj fotografiji iz 1980. (usp. Mehmedinović 2017: 134). Nije pahulja jer pahulje ni on, ni ona nisu „poznavali“ (Mehmedinović 2017: 122) sve dok ih nisu prvi put vidjeli nakon dvadeset godina života u Americi, iz njezine bolničke sobe u Washingtonu, D.C. Osim toga, ona „nikad nije voljela snijeg, užasavala ju je studen, posebno se taj osjećaj uvećao u hladnim ratnim zimama, u vrijeme opsade Sarajeva“ (Mehmedinović 2017: 122). Pahuljica, prema tome, kao deminutiv, ali i suprotnost pahulje, dobiva značenje mladosti, nježnosti, krhkosti, mira, života, radosti, sreće, ljepote, te predmeta umjetnosti, a onda i nostalgije, i to „reflektivne nostalgije“ koja se tiče pojedinca, njegove čežnje, gubitka i sjećanja za koje se čini da će biti izgubljeno u zaboravu ako se ne evocira (usp. Bojm 2005). Oznaka pahuljicom označava i njegovo i njezino, i njihovo zajedničko transmigrantsko bivanje $u$ Americi i čežnju za izgubljenim domom, bez imalo patetike i jugonostalgičnosti.

Svi su identiteti u fokusu ovoga rada, između ostalih, dio identiteta hibridnog, poližanrovskog i transdiskurzivnog teksta Mehmedinovićeva (trans)romana. Semezdin Mehmedinović je za Me’meda, сrvenu bandanu i pahuljicu 2018. dobio nagradu „Meša Selimović“ za najbolji roman objavljen 2017. na govornom prostoru Bosne i Hercegovine, Crne Gore, Hrvatske i Srbije, i to u okviru 18. književnih susreta „Cum grano salis“ u Tuzli, kao i nagradu „Mirko Kovač“ za najbolji roman, ponovno na području Bosne i Hercegovine, Crne Gore, Hrvatske i Srbije, a u okviru 5. Dana Mirka Kovača u Rovinju. (Trans)tekstualnom slobodom, izrazom i formom, između ostaloga, prevođenja života u književnost, i obratno, Me’med, crvena bandana i pahuljica potiče na propitivanje svijeta i, isto tako, na njegovo novo sagledavanje, i umom, kritičkim razmišljanjem, znanjem te saznavanjem, i osjećajima i čulima. Mehmedinovićeva konceptualna književnost iskazuje i ukazuje na čovjeka, ogoljava ga do srži i izriče njegovu suštinu, kao i iskonsku vrijednost života - ljubav, ali i njezine suprotnosti. Pri svemu tome kao jedno od pitanja nameće se i to jesmo li svi na neki način hibrid(n)i i upravo original(n)i kao takvi. Ili, postoji li uopće nešto što se u političkom konceptu naziva „čistim identitetom“? 


\section{Izvor}

Mehmedinović, Semezdin. 2017. Me’med, crvena bandana i pahuljica. Zaprešić: Fraktura.

\section{Literatura}

Anderson, Benedikt. 1998. Nacija: zamišljena zajednica. Beograd: Plato.

Bašić, Adisa. 2018. Svako naše sjećanje je fikcija: Intervju sa Semezdinom Mehmedinovićem. Novi izraz 71-72, 113-120.

Bojm, Svetlana. 2005. Budućnost nostalgije. Beograd: Geopoetika.

Caruth, Cathy. 1996. Unclaimed Experience: Trauma, Narrative, and History. Baltimore i London: The John Hopkins University Press.

Đorđević, Mira. Autobiografija između ispovijesti i hronike. Sarajevske sveske 13. URL: http://sveske.ba/en/content/autobiografija-izmedu-ispovijesti-i-hronike (11. 12. 2019.)

Irr, Caren. 2014. Toward the Geopolitical Novel: U.S. Fiction in the Twenty-First Century. New York: Columbia University Press.

Iyall Smith, Keri E. 2008. Hybrid Identities: Theoretical Examination. U: Hybrid Identities: Theoretical and Empirical Examination. Iyall Smith Keri E. i Patricia Leavy, ur. Leiden i Boston: Brill, 3-11.

Jergović, Miljenko. Knjiga o obitelji, egzilu, samoći i zaboravu, o rađanju Trumpove ere. Subotnja matineja. URL: https://www.jergovic.com/subotnja-matineja/knjiga-o-obitelji-egzilu-samoci-i-zaboravu-o-radanju-trumpove-ere/ (23. 4. 2019.)

Laffal, Julius. 1964. Freud's Theory of Language. U: The Psychoanalytic Quarterly 33-2, 157-175.

Ljevak, Kristina. Meni se već sve dogodilo: Intervju sa Semezdinom Mehmedinovićem. Urban magazin. URL: https://www.urbanmagazin.ba/semezdin-mehmedinovic-meni-se-vec-sve-dogodilo/ (24. 4. 2019.)

Mehmedinović, Semezdin. Re: Pitanje zbog naučnog rada: Me’med, crvena bandana i pahuljica. Email Selmi Raljević (5. 12. 2019.)

Mijatović, Aleksandar. 2009. Trauma i pitanje reprezentacije: suvremena teorija traume, Sigmund Freud i Walter Benjamin. U: FLUMINENSIA 21-2, 143-162.

Nail, Thomas. 2015. The Figure of the Migrant. Stanford: Stanford University Press.

Nikolić, Maja. BiH je tužna zemlja: Intervju sa Semezdinom Mehmedinovićem. Radio Slobodna Evropa. URL: https://www.slobodnaevropa.org/a/intervju-semezdin-mehmedinovic/29518660.html (23. 4. 2019.)

Otvaranje V. književnog festivala Poligon: Semezdin Mehmedinović i Josip Mlakić u razgovoru s Alminom Kaplanom. Hrvatsko narodno kazalište Mostar. (10. 10. 2019.)

Radeljković, Zvonimir. 2004. Mi u Pustoj zemlji: Pogovor. U: Eliot, T. S. Pusta zemlja. Zvonimir Radeljković, prevod i bilješke. Sarajevo: Buybook, 77-99.

Raljević, Selma. 2016. Novi izrazi: poetika modernosti savremenog romana. Novi izraz 65-66, 12-32. 
Schiller Glick, Nina, et al. 1992. Transnationalism: A New Analytical Framework for Understanding Migration. U: Towards a Transnational Perspective on Migration: Race, Class, Ethnicity, and Nationalism Reconsidered, Schiller Glick, Nina, et al. New York: New York Academy of Sciences, 1-24.

Solar, Milivoj. 1991. Teorija književnosti. Zagreb: Školska knjiga.

Vertovec, Steven. 2009. Transnationalism. London: Routledge. 


\title{
MULTI-GENRE AND TRANSDISCURSIVE TEXTUALITY OF SEMEZDIN MEHMEDINOVIĆ'S (TRANS) NOVEL ME'MED, RED BANDANA AND SNOWFLAKE
}

\begin{abstract}
Selma RALJEVIĆ

Dzemal Bijedic University of Mostar

Sjeverni logor bb, Univerzitetski kampus

$\mathrm{BiH}-88104$ Mostar

selma.raljevic@unmo.ba
\end{abstract}

Semezdin Mehmedinovićs 2017 hybrid (trans)novel Me'med, Red Bandana and a Snowflake (Me'med, crvena bandana i pahuljica) employs a conceptual art medium to present its content. Among others, it deals with the themes of identity, memory and memory loss, trauma, war, migration, belonging, nostalgia, health, family, love, and art. Being himself a transnational Post-Yugoslav Bosnian and Herzegovinian/South Slavic/ Eastern European-American writer with immigrant experience, Mehmedinović challenges the normative conception of identity by exploring identity construction in terms of personal and social identity as well as of the identity of narrative that disrupt the idea of "pure" identity. In its multi-genre, trans-discursive and trans-artistic storytelling, the novel shows the need of abandoning the idea of pure identity and embracing instead hybridity, which, among other things, envisions a coexistence of differences, deconstructs the construction of binaries (whether between nations, cultures, races, classes, or genders), and also reflects and (re)shapes many key features of contemporary human experience, configuring the realm of transgressed "imaginary" borders and articulating a voice of unassimilable identity of alterity.

Keywords: Me'med, Red Bandanna and a Snowflake (Me'med, crvena bandana i pahuljica), Semezdin Mehmedinović, hybrid, multi-genre, trans-discursive and trans-artistic narrative, identity, memory and memory loss. 